https://doi.org/10.31470/2706-7904-2021-16-240-243

\title{
ВИКОРИСТАННЯ СЕМАНТИЧНИХ ТЕХНОЛОГІЙ В ЕЛЕКТРОННОМУ НАВЧАННI
}

The Use of Semantic Technologies in E-Learning

\author{
Valentyna Pleskach \\ Dr. Sc. in Economics, Professor \\ Taras Shevchenko National University of Kyiv (Ukraine) \\ v_pleskach@ukr.net \\ Yuliya Rogushina \\ Ph.D. in Physics and Mathematics, Associate Professor \\ Institute of Software Systems of the National Academy of Sciences of Ukraine \\ ladamandraka2010@gmail.com
}

\begin{abstract}
Absrtact
This article is devoted to one of the basic directions of information technology (IT) development through its semantization, i.e. information processing at the level of values using the knowledge of the corresponding subject area (SAR). Semantic IT fundamentally changes the practice of education, ensuring its personalization.
\end{abstract}

Key words: formal languages, semantic information technology, Semantic Web.

\section{Вступ \\ Introduction}

Електронне навчання в даний час виступає важливою сферою застосування семантичних IT, оскільки сам процес навчання безпосередньо пов'язаний із передачею знань від одних суб'єктів до інших, а електронне навчання передбачає, що цей процес здійснюється автоматизовано, за тем, безпосередньо пов'язаний з обміном знаннями між викладачем та студентом, виникає потреба використовувати формалізоване інтероперабельне подання знань. При цьому під знаннями розуміють сукупність відомостей, фактів, понять, подань про що-небудь, накопичених у результаті навчання, досвіду, діяльності та в процесі встановлення різних видів залежностей між ними. 
Mema cmammi полягає у тому, щоб продемонструвати яким чином інтелектуальні інформаційні системи (IIC), що створені на основі семантичного niдxодy, відрізняються від традиційних, як вони сприяють розвитку прикладної психолінгвістики, зокрема психолінгвістики 3ВО.

\section{Методи дослідження Methods of the Research}

Це дослідження реалізовувалося завдяки сукупності теоретичних методів: системного аналізу семантичних технологій, порівняння цілеспрямованих інформаційних систем, узагальнення результатів веб-семантичного системного аналізу.

\section{Результати \\ Results}

Проведене теоретичне дослідження, яке має безпосереднє відношення до прикладної психолінгвістики, зокрема розв’язання проблем Semantic Web, засвідчило, що інтелектуальні інформаційні системи, створені на основі семантичного підходу, відрізняються від традиційних тим, що вони використовують явно виражені, наприклад з використанням формальних мов подання онтологій, знання ПрО, де онтологія виступає як модель і засіб формалізації знань. Ці системи застосовують методи, запозичені зі штучного інтелекту (Ш), які забезпечують ефективну обробку, аналіз та генерацію нових знань. Крім того, значна частина сучасних IC орієнтована на розподілену обробку інформації та на функціювання у відкритому інформаційному просторі Web, причому частка таких систем, у загальній кількості створюваних IIC, постійно зростає. IIC, що працюють у відкритому розподіленому інформаційному просторі, потребують постійного оновлення знань, що надходять із зовнішнього середовища. Основним джерелом таких знань у розподілених застосуваннях $\epsilon$ різноманітні інформаційні ресурси (IP) Web.

Основними компонентами семантичних IT (Рогушина, 2021) є: (1) онтології; (2) моделі сутностей, які обробляються в IIC; i (3) семантичні IP. Семантичні IP, що представлені у Web, не зводяться тільки до природномовних документів, і можуть містити мультимедійні або частково структуровані елементи, що супроводжуються семантичною розміткою. Саме наявність такої розмітки дозволяє автоматизовано пов'язувати елементи контенту IP з поняттями ПрО, що містяться у відповідних онтологіях.

Онтології $\epsilon$ інтероперабельним представленням знань та повторного використання знань, для яких сьогодні створюються загальновизнані стандарти та 
мови представлення. Перспективним підходом до вирішення цих проблем $\epsilon$ онтологічний аналіз: онтологї базуються на грунтовному теоретичному базисі дескриптивних логік, для них вже створено загальноприйняті стандарти опису, мови та програмні засоби.

На базі концепції Semantic Web (Davies, Fensel \& Harmelen, 2002) i використання формалізованих (певним способом) знань забезпечується інтелектуалізація IIC та застосувань у різних сферах людської діяльності, наприклад, інтелектуалізація мережних систем керування, створення прикладних інтелектуальних інформаційних систем і застосувань для медицини і е-бізнесу, для підвищення якості сервісів у мережі, оперативного вирішення задачі інформаційного захисту тощо.

Робота зі знанням - це достатньо складний багатоетапний процес, який має власний життєвий цикл. Як і будь-який процес, і тим більше складний, він потребує усвідомленого керування для забезпечення певної послідовності, погодженості, інтероперабельності, ефективності. Електронне навчання має певну специфіку, i важливими елементами його життєвого циклу $є$ контроль результатів навчання, забезпечення зворотного зв'язку між студентами та викладачами та оцінювання (валідація) здобутих внаслідок навчання компетенцій.

Для семантизації цієї діяльності доцільно застосовувати онтології різних рівнів: від онтологій верхнього рівня (для встановлення найбільш узагальнених зв'язків між поняттями) та міжнародних стандартів кваліфікацій та компетенцій (таких, як ESCO) до онтологій ПрО та задач, що характеризують окремі навчальні курси (Rogushina, Gladun, Pryima \& Strokan, 2020). Такі онтології можна повторно використовувати, знаходячи їх у різноманітних репозиторіях, або генерувати відповідно до потреб конкретного застосування за семантично розміченими IP Web (наприклад, за семантизованими Wiki) (Krotzsch, Vrandecic \& Volkel, 2021).

\section{Висновки Conclusions}

Особливості обробки онтологічних знань в процесі електронного навчання визначаються цілями та специфікою окремих застосувань, але більшість сучасних IIC в цій області орієнтовані на підтримку стандартів Semantic Web та обробку знань в форматах OWL та RDF. 


\section{Література \\ References}

OWL 2 Web Ontology Language Document Overview. W3C. (2009). Retrieved from http://www.w3.org/TR/owl2-overview/ (accessed 2021, 15 Oct).

Рогушина, Ю.В. (2020). Основні компоненти семантичних технологій. Плескач, В.Л. \& Міронова, В.Л. (Ред), Тези V Міжнародної науково-практичної конференції «Прикладні системи та технології в інформаційному суспільстві» (Київ, 30 вересня 2020 року), (с. 194-200).

Davies, J., Fensel, D., \& Harmelen, van F. (Ed.). (2002). Towards the Semantic Web: Ontologydriven knowledge management.

Rogushina, J.V., Gladun, A.Y., Pryima, S.M., \& Strokan, O.V. (2019). Ontology-Based Approach to Validation of Learning Outcomes for Information Security Domain. CEUR Workshoop Proceedings, 2577, 21-36.

Krotzsch, M., Vrandecic, D., \& Volkel, M. (2021). Semantic MediaWiki. (accessed 2021, Nov 15).

Krötzsch, M., Vrandečić, D., \& Völkel, M. (2006). Semantic mediawiki. International semantic web conference, $935-942$. 